\title{
Effect of emodin on $T$ cell subsets in NOD mice with NaI-induced experimental autoimmune thyroiditis
}

\author{
HUAQIN SUN ${ }^{1 *}$, ZHIPENG YE ${ }^{2 *}$, NING LI $^{2}$, FA JIN ${ }^{2}$, JIULIANG YAN $^{2}$ and KEREN WU ${ }^{2}$ \\ Departments of ${ }^{1}$ Anesthesiology and ${ }^{2}$ Hepatobiliary Surgery, \\ The First Affiliated Hospital of Zhejiang Chinese Medical University, Hangzhou, Zhejiang 310006, P.R. China
}

Received February 22, 2018; Accepted August 21, 2018

DOI: $10.3892 / \mathrm{mmr} .2018 .9434$

\begin{abstract}
Chronic lymphocytic thyroiditis (CLT), also known as Hashimoto's thyroiditis, is an autoimmune disease in which the thyroid gland is gradually destroyed. To date, only a limited number of agents can effectively suppress thyroiditis development in CLT patients. The aim of the current study was to investigate the protective effect of emodin on experimental autoimmune thyroiditis (EAT) in mice, which is considered an excellent model for CLT. NaI was used to induce the EAT model in non-obese diabetic (NOD) mice. An ELISA method was employed to detect the TgAb level (thyroid inflammation) in the serum of the EAT mice. The T cell subsets in peripheral blood and spleen were detected by flow cytometry. The histopathological study revealed that the thyroid inflammatory cell infiltration was significantly reduced by emodin compared with the model group. In addition, ELISA assays indicated that the NaI-induced serum $\mathrm{TgAb}$ upregulation was dramatically revered by emodin. Moreover, the level of serum IFN $-\gamma$ and the cell populations of $\mathrm{CD}_{3}{ }^{+} \mathrm{CD}_{4}{ }^{+} \mathrm{IL}-4^{+}, \mathrm{CD}_{3}{ }^{+} \mathrm{CD}_{4}{ }^{+} \mathrm{IFN}-\gamma^{+}$, $\mathrm{CD}_{3}{ }^{+} \mathrm{CD}_{8}^{+} \mathrm{IL}_{-} 4^{+}, \mathrm{CD}_{3}{ }^{+} \mathrm{CD}_{8}{ }^{+} \mathrm{IFN}-\gamma^{+} \mathrm{T}$ cells in peripheral blood monocytes and splenic lymphocytes were significantly increased by $\mathrm{NaI}$ in the model group compared with in the normal group. Nevertheless, this type of increase was markedly attenuated by emodin. To conclude, the EAT model was successfully established by treating NOD mice with NaI. Emodin indicated an inhibitory effect on the autoimmune response that was significantly different in EAT compared with control mice. Furthermore, the anti-inflammatory action of emodin on EAT mice may be mediated via the inhibition of the secretion of IFN- $\gamma$ and the cell numbers of $\mathrm{CD}_{3}{ }^{+} \mathrm{CD}_{4}{ }^{+} \mathrm{IL}-4^{+}$,
\end{abstract}

Correspondence to: Dr Keren Wu, Department of Hepatobiliary Surgery, The First Affiliated Hospital of Zhejiang Chinese Medical University, 54 You Dian Road, Hangzhou, Zhejiang 310006, P.R. China

E-mail:wu_keren@126.com

${ }^{*}$ Contributed equally

Key words: emodin, chronic lymphocytic thyroiditis, experimental autoimmune thyroiditis, autoimmune response
$\mathrm{CD}_{3}{ }^{+} \mathrm{CD}_{4}{ }^{+} \mathrm{IFN}-\gamma^{+}, \mathrm{CD}_{3}{ }^{+} \mathrm{CD}_{8}{ }^{+} \mathrm{IL}-4^{+}$and $\mathrm{CD}_{3}{ }^{+} \mathrm{CD}_{8}{ }^{+} \mathrm{IFN}-\gamma^{+}$ $\mathrm{T}$ cells in the peripheral blood monocytes and splenic lymphocytes. Therefore, the data may offer valuable insight on the efficacy of treatment of CLT with emodin.

\section{Introduction}

Chronic lymphocytic thyroiditis (CLT) or Hashimoto's thyroiditis (HT) is a frequent disease characterized by autoimmune effects on the thyroid that are induced by the attack of cell-mediated immune process and various antibodies (1). CLT is related to specific thyroid malignancies and autoimmune thyroid diseases, such as papillary thyroid carcinoma (PTC) $(1,2)$. Iliadou et al provided evidence to support that adolescents and children who are born with CLT are susceptible to the familial PTC or other thyroid cancer with invasive characteristics (3). Children with CLT often show some common clinical manifestations including weight gain, weakness, cold intolerance and fatigue (4). Currently, symptomatic therapy is the only available method to treat CLT and as a result the development of new fundamental treatments for this disease is essential (4). Certain studies have shown that the imbalance between Th1 (such as IFN- $\gamma$ ) and Th2 cytokines, such as IL-4 and IL-10 play an important role in regulating CLT (4).

Experimental autoimmune thyroiditis (EAT) in animal models has been used to simulate human CLT (5). EAT can represent human CLT to some extent (5). EAT animal models can be induced by treatment with different materials. Certain reports have demonstrated that EAT can be induced in NOD mice by administration of NaI. This condition can also be induced by immunization with human thyroglobulin with Freund's adjuvant in CBA/J mice (6-9). Recently, EAT animal models have frequently been used in the majority of studies in order to simulate CLT and identify the proper mechanism involved in CLT. Using the EAT animal model, green tea polyphenols and modified Haizao Yuhu decoction were shown to be effective in the treatment of CLT $(6,8)$. To the best of our knowledge, the efficacy of the therapeutic treatment used for CLT is limited. Thus, there is an increased requirement for effective and novel treatments for CLT.

As one of the active ingredients in Rheum palmatum, emodin, namely 1,3,8-trihydroxy-6-methylanthraquinone is a naturally effective anthraquinone derivative. Emodin is also found in other plants such as Cassia obtusifolia, Aloe vera, 
Polygonum multiflorum and Polygonum cuspidatum (10). It has been shown that emodin has various pharmacological effects, including antitumor, anti-oxidative, liver protective, antifungal, antibacterial, antiviral and immunosuppressive activities (11-13). Among those activities of emodin, the immunosuppressive activity has been of particular interest. In vitro studies have shown that emodin can induce apoptosis in human T cells by increasing activated caspase-3, -4 and -9 (14). Another study suggested that emodin ameliorated the proliferation of peripheral blood mononuclear cells via the regulation of the balance between Th1 and Th-2 cytokines (10). Qiu et al, reported that emodin may act as a novel mTOR inhibitor, which inhibits alloimmunity via the reduction of the production of alloantibody, thus lowering the maturation process of dendritic cells and the regulation of both $\mathrm{CD}^{+} \mathrm{CD}^{2} 22^{+}$and $\mathrm{CD}^{+}{ }^{+} \mathrm{FoxP}^{+}{ }^{+}$Tregs (15). Taken collectively these studies suggest that emodin could be considered an emerging and effective immunosuppressant.

CLT is a disease, which is closely related to the imbalance of the immune system. CD3 T-lymphocytes, T helper lymphocytes (CD4) and cytotoxic T-lymphocytes (CD8) were considered to play a vital role in the regulation of CLT (16). To the best of our knowledge, there is no report regarding the effect of emodin on CLT. In the present study, the mechanism of action of emodin with regard to CLT was investigated using the EAT animal model. The data suggested that emodin may be useful in the treatment of CLT. Furthermore, we sought to investigate the underlying mechanisms involved in the treatment of CLT by emodin.

\section{Materials and methods}

Drugs and reagents. Fetal bovine serum (FBS, 10270-106) and RPMI-1640 (12633012) medium were purchased from Gibco (Thermo Fisher Scientific, Inc., Waltham, MA USA). Primary antibodies against CD3 (100217), CD4 (100412), CD8 (100703), IFN- $\gamma$ (582825) and IL-4 (504105), were obtained from Biolegend (Biolegend, Inc., San Diego, CA USA). TgAb ELISA kit was from Shanghai QiaoYu Biomedical Science and Technology Co., Ltd. (Shanghai, China). TBD Lymphocyte separation medium (LTS1092) was from Tianjin TBDscience Co., Ltd. (Tianjin, China). Disposable heparin tubes for human vein blood sampling $(310122,2016)$ were obtained from Jiangsu Kangjie Medical Devices Co., Ltd. (Jiangsu, China). The remaining commercial available reagents were all of analytical grade.

Animals and treatment. 7 week-old non-obese diabetic (NOD) mice were purchased from Vital River (Beijing, China). Following acclimation for 1 week under environmentally controlled conditions (food and water ad libitum, temperature $21-25^{\circ} \mathrm{C}$, relative humidity $40-60 \%, 12 \mathrm{~h}$ dark/light cycles), the animals were randomly divided into two groups, namely the normal group $(n=3)$ and the model group $(n=12)$. The animals in the normal and the model groups were allowed access to deionized water and/or $0.05 \% \mathrm{NaI}$ solution (containing $0.64 \mathrm{~g} \mathrm{NaI}$ per liter) for 5 weeks separately. From the fifth week, 9 animals ( 3 mice/group) in the model group were randomly selected and were orally provided 15,75 or $150 \mathrm{mg} / \mathrm{kg}$ emodin daily for 3 weeks. The remaining animals were administered orally normal saline daily for 3 weeks. All the animal procedures were approved by the First Affiliated Hospital of Zhejiang Chinese Medical animal experimental ethics committee (201708791).

Serum preparation. In the end of experiment, the animals were weighed and blood was obtained from the ophthalmic vein. Following natural coagulation at room temperature for 10 to $20 \mathrm{~min}$, the blood samples were centrifuged at $3,000 \mathrm{x} \mathrm{g}$ for $20 \mathrm{~min}$ at $4^{\circ} \mathrm{C}$. The supernatants were carefully collected and stored at $-80^{\circ} \mathrm{C}$ until further use.

Peripheral blood mononuclear cell (PBMC) separation. The blood collected on the last day was mixed with EDTA for anticoagulation. Following mixing with the same volume of Hank's solution, the blood was carefully added on top of $2 \mathrm{ml}$ of lymphocyte separation medium. The mixture was centrifuged at 2,000 x g for $15 \mathrm{~min}$. The cells that were in the interface were collected and mixed with 4 to $5 \mathrm{ml}$ of Hank's solution. Following sufficient mixing, the samples were centrifuged at $1,500 \mathrm{x}$ g for $5 \mathrm{~min}$ and the supernatant was discarded. The samples were finally washed twice and the residue that remained was the fraction that contained PBMC.

Separation of spleen lymphocytes. Following blood collection, the animals were sacrificed by pure $\mathrm{CO}_{2}$. The flow rate of $\mathrm{CO}_{2}$ was $1 \mathrm{l} / \mathrm{min}$. The spleens of the sacrificed animals were collected under aseptic conditions. The spleen was grinded using $5 \mathrm{ml}$ of mouse lymphocyte separation medium in a section screen cloth. The cell suspension was transferred into $1 \mathrm{ml}$ of RPMI-1640 medium in a centrifuge tube. The mixture was centrifuged at 2,200 $\mathrm{x}$ g for $20 \mathrm{~min}$ at room temperature. The lymphocytes in the middle of the centrifuge tube were gently gathered and washed twice using PBS. The lymphocytes were resuspended in RPMI-1640 containing 10\% FBS and counted.

Serum $T g A b$ ELISA assay. The serum protein level of $\mathrm{Tg} \mathrm{Ab}$ was detected using a $\mathrm{TgAb}$ ELISA kit according to the manufacturer's instruction. The serum samples in all groups were diluted 5 times by sample diluent. Subsequently, $100 \mu \mathrm{l}$ of the serum samples was added to a 96-well plate and incubated with the appropriate biotin conjugated antibodies at $37^{\circ} \mathrm{C}$ for $120 \mathrm{~min}$. The 96-well plate was washed 5 times with wash solution. A total of $50 \mu \mathrm{l}$ of substrate A and B were added to the 96-well plate separately and the samples were incubated at $37^{\circ} \mathrm{C}$ for $30 \mathrm{~min}$ in the dark. The reaction was terminated by addition of $50 \mu \mathrm{l}$ of the stop solution to the 96 -well plate. The optical density (OD) was determined using a microplate reader (Thermo Fisher Scientific, Inc., Waltham, MA, USA). A standard curve of $\mathrm{TgAb}$ was prepared according to the manufacture's instructions. All standards and samples were run in duplicate.

Detection of $T$ cells in PBMC and spleen lymphocytes. PreCP-Cy5.5-labeled anti-CD3, APC-conjugated anti-CD4, FITC-conjugated anti-CD8 and PE-conjugated Isotype Ctrl were purchased from Biolegend. The single cell suspension of PBMC and spleen lymphocytes was surface-marked with antibodies of each subpopulation at room temperature for $30 \mathrm{~min}$. 
Following washing with PBS and fixation with $4 \%$ paraformaldehyde, the cells were resuspended in permeabilization solution ( $0.1 \%$ saponin and $0.5 \%$ brefeldin A added in PBS). Intracellular staining of CD3, CD4 and CD8 was measured according to the instructions provided by the manufacturer. The difference in the population of $\mathrm{CD}^{+} \mathrm{CD}^{+}$and/or $\mathrm{CD}^{+} \mathrm{CD}^{+}$ $\mathrm{T}$ cells in each group was analyzed by flow cytometry (FCM) using intracellular staining (BD Biosciences, Franklin Lakes, NJ, USA). The CellQuest software (BD Biosciences) was used to analyze the data collected in the experiment.

Detection of of IFN- $\gamma$ and IL-4 in T cells of the spleen lymphocyte population. APC-CY7-A-conjugated anti-IL-4 and PE-CY7-conjugated anti-IFN- $\gamma$ were both purchased from Biolegend. PBMC and spleen lymphocytes were treated with $50 \mathrm{ng} / \mathrm{ml}$ phorbol ester and $1 \mu \mathrm{g} / \mathrm{ml}$ ionomycin for $6 \mathrm{~h}$ at $37^{\circ} \mathrm{C}$ in a humidified atmosphere containing $5 \% \mathrm{CO}_{2}$. Prior to the first hour of incubation, brefeldin A (BFA, $10 \mu \mathrm{g} / \mathrm{ml}$ ) was added. The cells were collected, washed with PBS twice and incubated with antibodies of each subpopulation at room temperature for $30 \mathrm{~min}$. Following washing with PBS, the cells were fixed with $4 \%$ paraformaldehyde and resuspended in permeabilization solution ( $0.1 \%$ saponin and $0.5 \%$ BFA added in PBS). The cells were subsequently incubated with intracellular cytokine staining antibodies at room temperature for $30 \mathrm{~min}$, washed and finally resuspended in cold staining buffer. The percentages of $\mathrm{CD}^{+}{ }^{+} \mathrm{CD} 4{ }^{+} \mathrm{IFN}-\gamma^{+}, \mathrm{CD}^{+} \mathrm{CD} 4^{+} \mathrm{IL}-4^{+}, \mathrm{CD}^{+}{ }^{+} \mathrm{CD} 8{ }^{+}$ IFN $-\gamma^{+}$and $\mathrm{CD}^{+} \mathrm{CD}^{+} \mathrm{IL}-4^{+} \mathrm{T}$ cells in each sample of the three groups were analyzed by flow cytometry. CellQuest software (BD Biosciences) was used to analyze the data collected in the experiment.

Histopathology of the thyroid. The animals were sacrificed with pure $\mathrm{CO}_{2}(1 \mathrm{l} / \mathrm{min})$ and the neck sections were dissected immediately. The thyroid was rapidly stripped below the thyroid cartilage. Following washing by cold saline, the thyroid was fixed in $4 \%$ formaldehyde solution for at least $24 \mathrm{~h}$. The thyroid was subsequently embedded in paraffin and $4 \mu \mathrm{m}$ slices were used and stained by hematoxylin and eosin (H\&E). The areas of the inflammatory cell and the thyroid were estimated by Image-pro Plus. The inflammatory ratio equals to the area of the inflammatory cell divided by the area of the thyroid. The evaluation process of this area was based on previous studies (17). The incidence of histological abnormalities consistent with EAT was graded as the function of the mononuclear cell thyroid infiltration as follows: degree 0 refers to normal thyroid, degree 1 refers to interstitial accumulation of inflammatory cells distributed between two or more follicles, degree 2 refers to one or two foci of inflammatory cells reaching at least the size of one follicle, degree 3 refers to 10 to $40 \%$ of the thyroid replaced by inflammatory cells, degree 4 refers to more than $40 \%$ of the thyroid replaced by inflammatory cells. The inflammatory ratio was used to evaluate the percentage of the thyroid cells replaced by inflammatory cells. The estimation of the inflammatory ratio (\%) was performed as follows: the number of inflammatory cells/ the total cells in this view $\mathrm{x} 100$. The slides were scored in a blinded manner. The mean scores were calculated by counting 10 different fields for each group under a light microscope with the same method. The details of this methodology are shown in Table I.
Table I. Details of standard for evaluation for inflammatory condition of the thyroid.

\begin{tabular}{lc}
\hline Histopathology degree & Inflammatory ration $(\%)$ \\
\hline 0 & 0 (normal thyroid) \\
1 & $<1$ \\
2 & $1-10$ \\
3 & $10-40$ \\
4 & $>40$ \\
\hline
\end{tabular}

Table II. Pathological grading of thyroid in experimental autoimmune thyroiditis non-obese diabetic mice after different treatment in each group.

Thyroid

\begin{tabular}{llc} 
Group & $\mathrm{n}$ & pathological grade \\
\hline Normal group & 3 & 0 \\
Model group & 3 & $4.00^{1}$ \\
$15 \mathrm{mg} / \mathrm{kg}$ emodin & 3 & 3.00 \\
$75 \mathrm{mg} / \mathrm{kg}$ emodin & 3 & $2.00^{2}$ \\
$150 \mathrm{mg} / \mathrm{kg}$ emodin & 3 & 3.00 \\
$\mathrm{P}^{1}$ & $/$ & $<0.001$ \\
$\mathrm{P}^{2}$ & $/$ & $<0.001$
\end{tabular}

Thyroid pathological grade was based on the results of histopathology. Slides were scored in a blinded manner. Mean scores were calculated by counting 10 different fields for each group under a light microscope with the same method. $\mathrm{P}^{1}<0.001$, Model group vs. normal group; $\mathrm{P}^{2}<0.001,75 \mathrm{mg} / \mathrm{kg}$ emodin vs. model group.

Statistical analysis. The data were analyzed by GraphPad Software, Inc. (La Jolla, CA, USA; Version 5). All values were expressed as mean \pm standard deviation. Comparisons between groups were analyzed using one-way ANOVA analysis followed by Dunnett's post hoc test. $\mathrm{P}<0.05$ was considered to indicate a statistically significant difference.

\section{Results}

Histopathology of thyroid inflammation. The examination of the thyroid follicles by optical microscopy revealed normal morphology. The size of the normal thyroid was consistent. The normal thyroid epithelial cells were grown as a monolayer in a cuboidal shape or a column (Fig. 1). Following treatment by $\mathrm{NaI}$, the structure of the thyroid follicle was destroyed. The epithelial cells were compressed and the mesenchyme was reduced. An apparent mononuclear cell infiltration was noted in the model group (Fig. 1). According to the histopathological evaluation, thyroid inflammation was evident in the model group to a higher extent compared with that noted in the normal group. In addition, the comparison of the low dose and/or high dose of emodin, with the middle dose treatment ( $75 \mathrm{mg} / \mathrm{kg}$ emodin) suggested that this treatment exerted the best anti-inflammatory effect on EAT mice (Table II). Hence, 
A

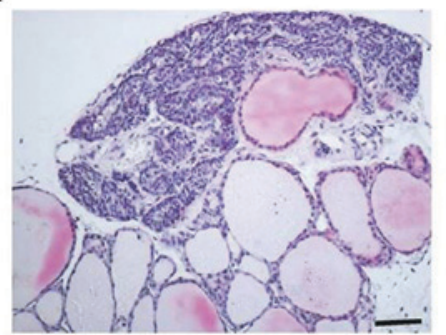

Normal

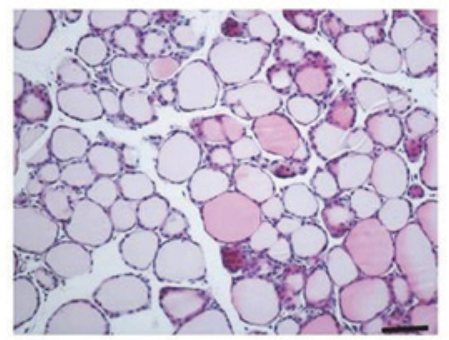

Model

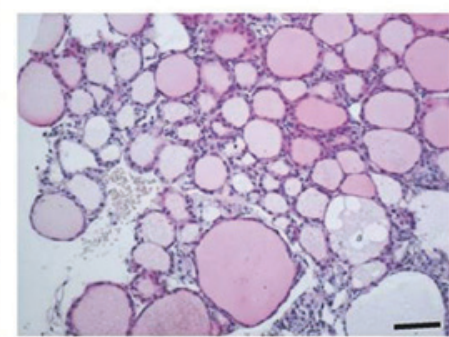

Emodin

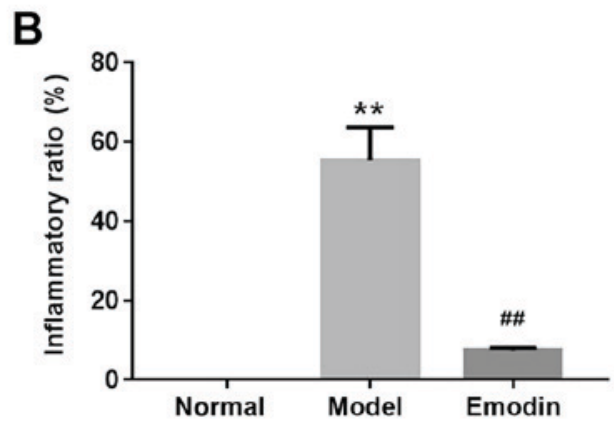

Figure 1. Effect of emodin on the thyroid gland of EAT NOD mice. (A) Normal group: animals were allowed access to water and were treated with saline. Model group: Animals were administered $0.05 \%$ iodine deionized water and treated with saline. Emodin group: animals were administered $0.05 \%$ iodine deionized water and treated with $75 \mathrm{mg} / \mathrm{kg}$ emodin. Subsequently, tissues obtained from treated mice were stained with hematoxylin and eosin. $\mathrm{n}=3$ in each group. (10x magnification, scale bar: $100 \mu \mathrm{m}$ ). (B) The Inflammatory ratio in each group was quantified. ${ }^{* *} \mathrm{P}<0.01 \mathrm{vs}$. normal group; ${ }^{\# \#} \mathrm{P}<0.01 \mathrm{vs}$. model group. Mean \pm standard deviation from three independent experiments. EAT, experimental autoimmune thyroiditis; NOD, non-obese diabetic.

$75 \mathrm{mg} / \mathrm{kg}$ of emodin was selected as the optimum dose for the following experiments.

Emodin attenuated the expression of $\mathrm{TgAb}$ in NaI-induced EAT mice. $\mathrm{Tg} \mathrm{Ab}$ is only located in the thyrocytes and is not secreted in the blood under normal condition unless in cases of chronic inflammation (3). During chronic inflammation, the immune system is stimulated to excrete $\mathrm{Tg} \mathrm{Ab}$ for the production of relative antibodies. Therefore, $\mathrm{TgAb}$, a type of serum thyroid autoantibody, was considered a special biomarker for the diagnosis of CLT. In the present study, TgAb levels in the serum were measured by ELISA $(17,18)$. The TaAb protein levels in EAT NOD mice of the model group were significantly increased compared with those noted in the normal group (Fig. 2). The expression of this protein was dramatically decreased by emodin partly via the reduction of the $\mathrm{Tg} \mathrm{Ab}$ protein levels. In addition, the isotype control itself had no effect on the relative population of $\mathrm{CD} 3^{+} \mathrm{CD} 4^{+} \mathrm{T}$ cells derived from PBMC and spleen lymphocytes in the EAT NOD mice.

Emodin suppressed the relative population of $\mathrm{CD}^{+} \mathrm{CD}^{+} \mathrm{T}$ cells of PBMC and spleen lymphocytes in EAT NOD mice. In EAT NOD mice (model group), the relative population of $\mathrm{CD}^{+} \mathrm{CD}^{+} \mathrm{T}$ cells in PBMC and spleen lymphocytes was markedly increased compared with the normal group, which indicated that EAT may be related to the high level of $\mathrm{CD}^{+} \mathrm{CD}^{+} \mathrm{T}$ cells (Fig. 3A and B). In addition, emodin significantly decreased the relative population of $\mathrm{CD}^{+} \mathrm{CD}^{+} \mathrm{T}$ cells in PBMC and spleen lymphocytes, which indicated that emodin could lower the EAT level partly by reducing the relative population of $\mathrm{CD}^{+} \mathrm{CD} 4^{+} \mathrm{T}$ cells in $\mathrm{PBMC}$ and spleen lymphocytes (Fig. 3A and B).

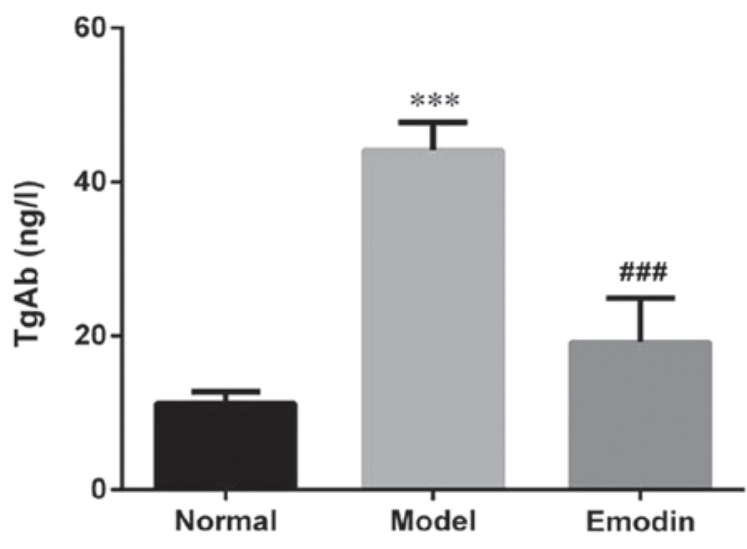

Figure 2. A total of $75 \mathrm{mg} / \mathrm{kg}$ emodin attenuated the protein levels of $\mathrm{TgAb}$ in EAT NOD mice induced by NaI. The protein levels of TgAb in each group after different treatment. The protein levels of $\mathrm{TgAb}$ were measured using an ELISA kit. ${ }^{* * *} \mathrm{P}<0.001$ vs. normal group; ${ }^{\# \#} \mathrm{P}<0.001$ vs. model group. Mean \pm standard deviation from three independent experiments. EAT, experimental autoimmune thyroiditis; NOD, non-obese diabetic.

Emodin reduced the relative population of $C D 3^{+} C D 8^{+} T$ cells of PBMC and spleen lymphocytes in EAT NOD mice. The relative population of $\mathrm{CD}^{+} \mathrm{CD}^{+} \mathrm{T}$ cells of $\mathrm{PBMC}$ and spleen lymphocytes was increased in the model group compared with the normal group, suggesting that EAT may be related to the high level of $\mathrm{CD}^{+} \mathrm{CD}^{+} \mathrm{T}$ cells (Fig. 4A and B). However, treatment with emodin reduced significantly the relative population of $\mathrm{CD}^{+}{ }^{+} \mathrm{CD} 8{ }^{+} \mathrm{T}$ cells in the PBMC and spleen lymphocytes compared with the model group, which suggests that emodin attenuated the severity of EAT partly by decreasing the relative population of $\mathrm{CD}^{+} \mathrm{CD}^{+} \mathrm{T}$ cells in PBMC and spleen lymphocytes. 
A

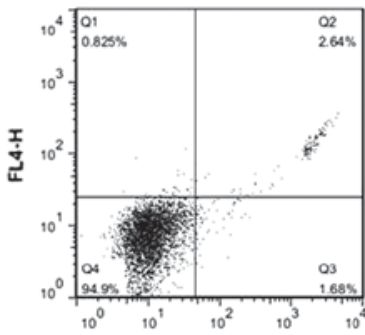

FL3.H

Isotype control

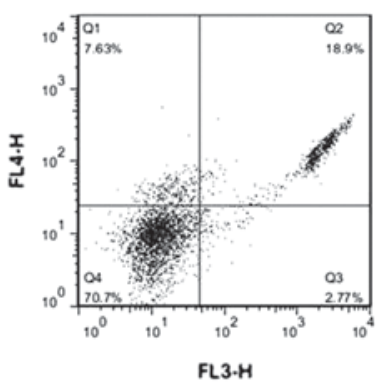

Model

B
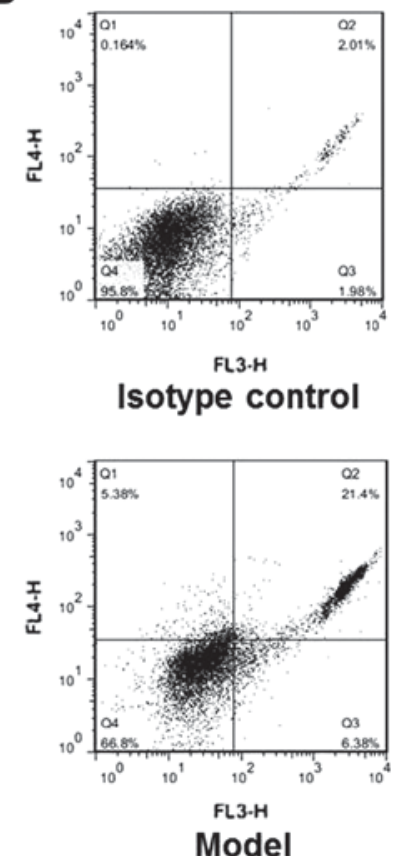

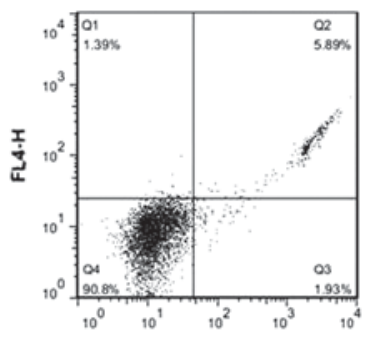

FL3.H

Normal

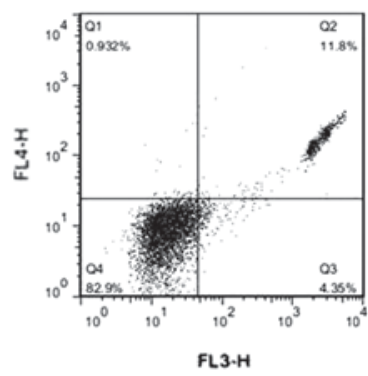

Emodin

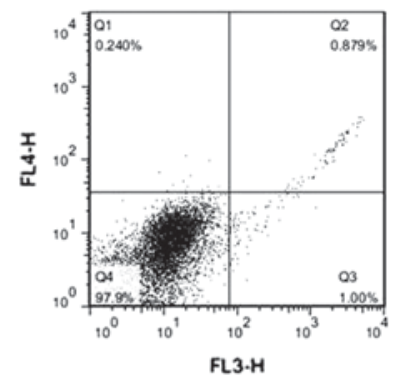

Normal

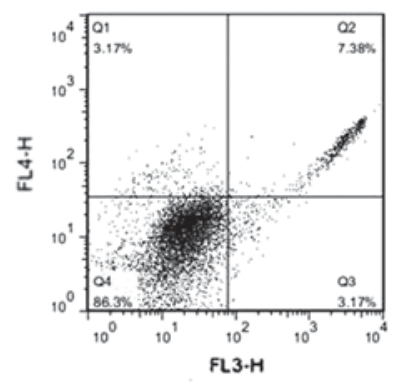

Emodin
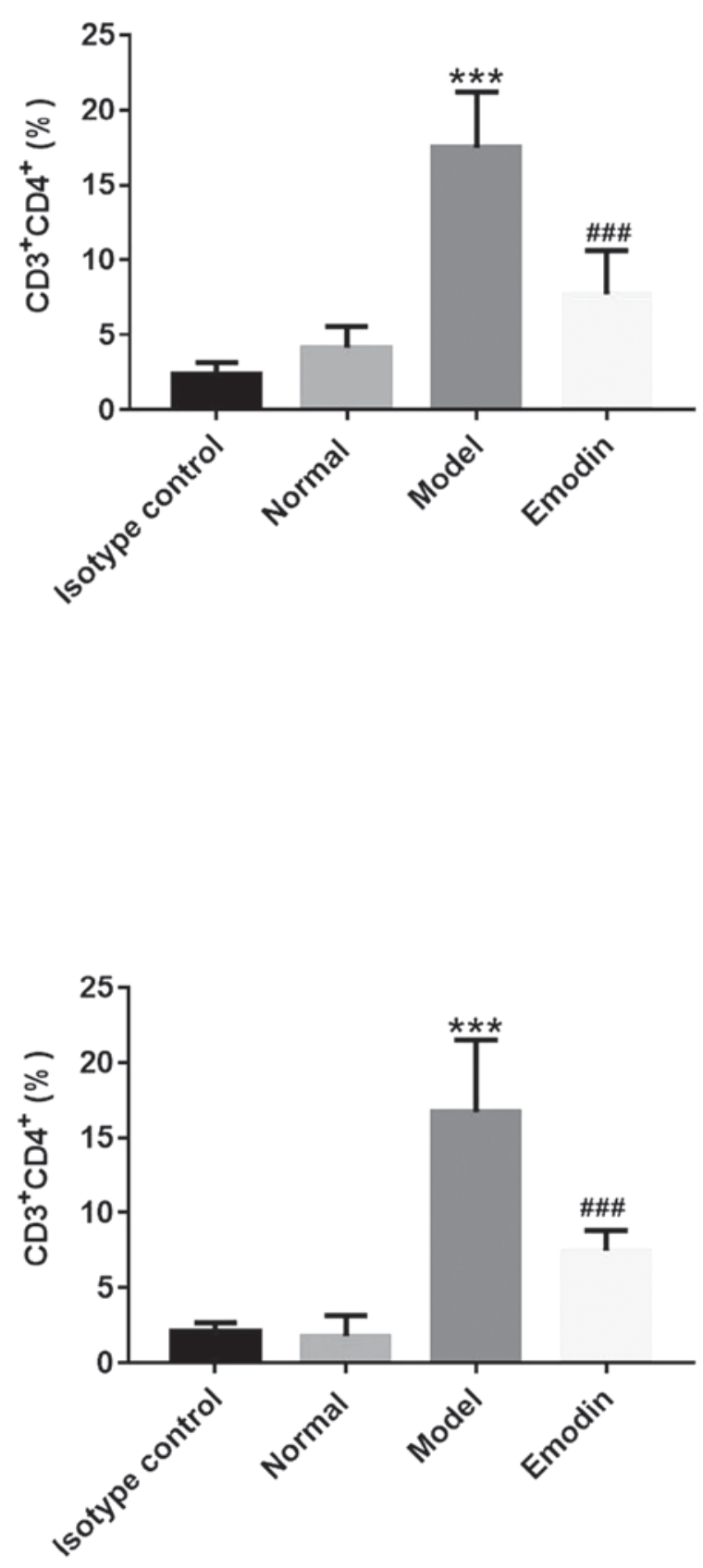

Figure 3. A total of $75 \mathrm{mg} / \mathrm{kg}$ emodin suppressed the relative population of $\mathrm{CD} 3^{+} \mathrm{CD} 4^{+} \mathrm{T}$ cells of PBMC and spleen lymphocytes in EAT mice. Following treatment with $0.05 \%$ iodine water, animals with EAT were observed. The blood and spleen of all the animals (Isotype ctrl, normal, model or $75 \mathrm{mg} / \mathrm{kg}$ emodin group, $n=3$ in each group) were collected. PBMC and spleen lymphocytes were separated according to the method mentioned above. The relative population of $\mathrm{CD}^{+} \mathrm{CD} 4^{+} \mathrm{T}$ cells of PBMC and spleen lymphocytes was analyzed by Flow cytometry. The relative population of $(\mathrm{A}) \mathrm{CD} 3^{+} \mathrm{CD} 4^{+} \mathrm{T}$ cell of PBMC and $(\mathrm{B})$ spleen lymphocytes. ${ }^{* * *} \mathrm{P}<0.001$ vs. normal group; ${ }^{\# \# \#} \mathrm{P}<0.001$ vs. model group. Mean \pm standard deviation from three independent experiments. PBMC, peripheral blood mononuclear cell; EAT, experimental autoimmune thyroiditis.

Emodin decreased the relative populations of $C D 3^{+} C D 4^{+} I F N-\gamma^{+}$and $C D 3^{+} C D 4^{+} I L-4^{+} T$ cells of $P B M C$ and spleen lymphocytes in EAT NOD mice. Following treatment with $\mathrm{NaI}$, the relative frequencies of $\mathrm{CD} 3^{+} \mathrm{CD} 4^{+} \mathrm{IFN}-\gamma^{+}$and $\mathrm{CD}^{+}{ }^{+} \mathrm{CD} 4^{+} \mathrm{IL}-4^{+} \mathrm{T}$ cells of PBMC and spleen lymphocytes were increased in NOD mice of the model and the emodin groups compared with the normal group (Fig. 5A and B). Treatment with emodin decreased the relative populations of $\mathrm{CD} 3{ }^{+} \mathrm{CD} 4{ }^{+} \mathrm{IFN}-\gamma^{+}$and $\mathrm{CD} 3{ }^{+} \mathrm{CD} 4^{+} \mathrm{IL}-4^{+} \mathrm{T}$ cells of PBMC and spleen lymphocytes (Fig. 5A and B). The data suggested that 
A

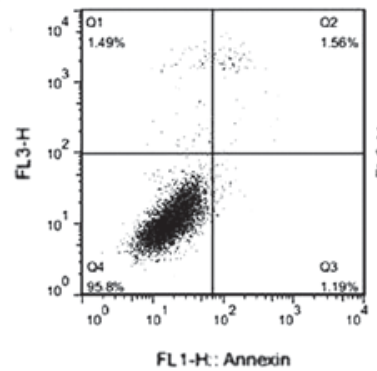

FL 1.H: Annesin
Isotype control

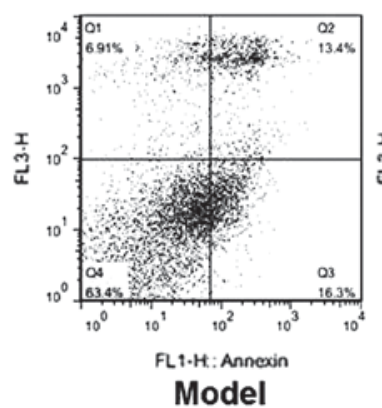

Model

B

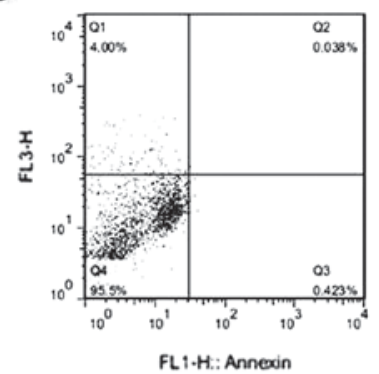

Isotype control

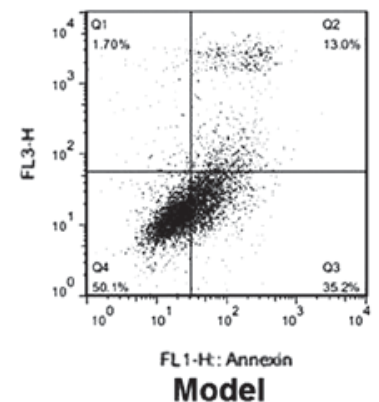

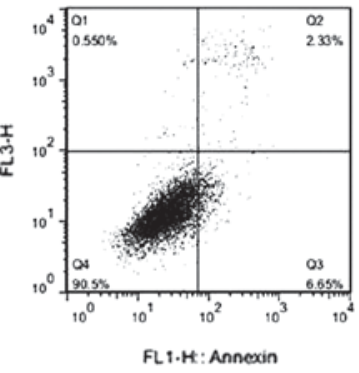

Normal
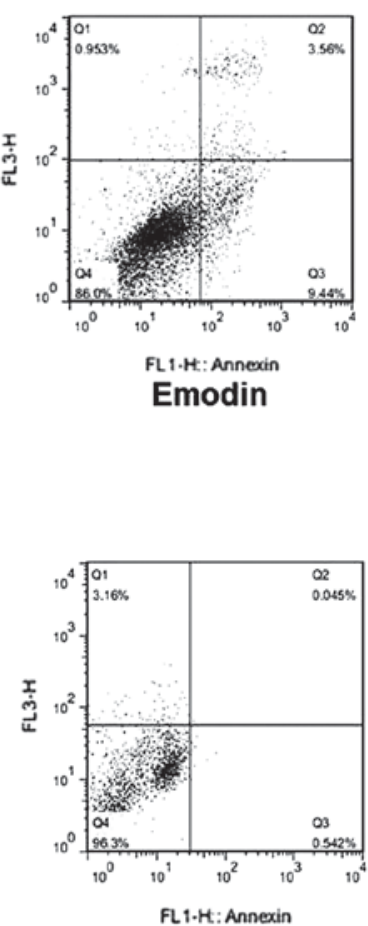

Normal

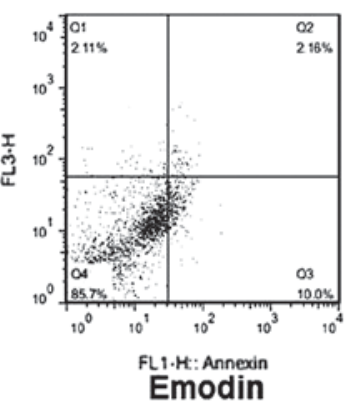

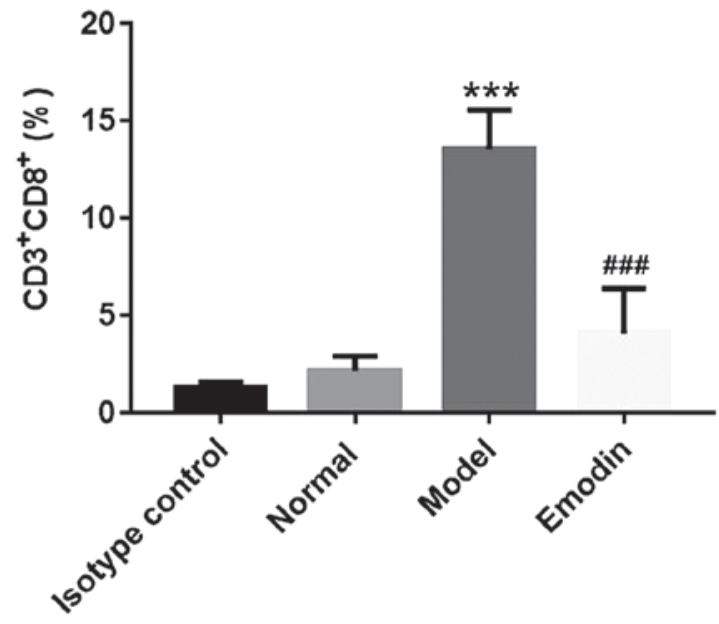

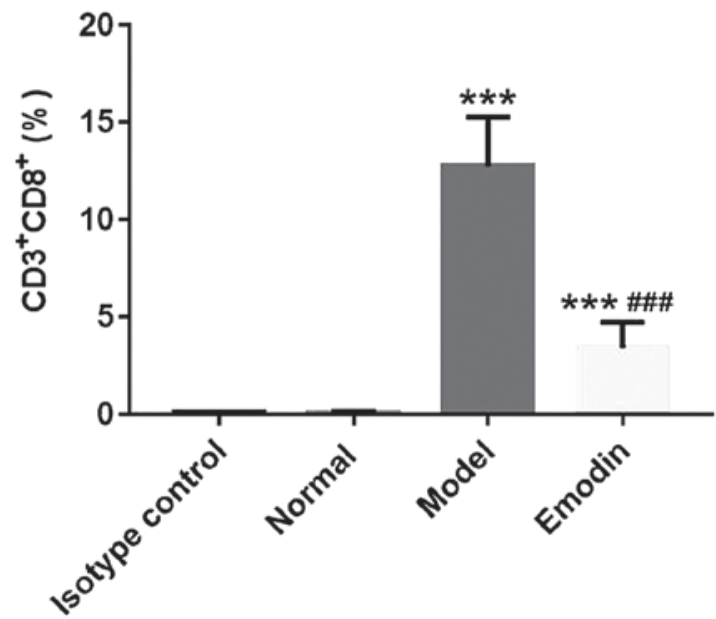

Figure 4. A total of $75 \mathrm{mg} / \mathrm{kg}$ emodin reduced the relative population of $\mathrm{CD}^{+} \mathrm{CD} 8^{+} \mathrm{T}$ cells of PBMC and spleen lymphocytes in EAT mice. The relative population of $\mathrm{CD}^{+} \mathrm{CD} 8{ }^{+} \mathrm{T}$ cells in $\mathrm{PBMC}$ and spleen lymphocytes was analyzed by flow cytometry. The relative population of $(\mathrm{A}) \mathrm{CD}^{+} \mathrm{CD} 8^{+} \mathrm{T}$ cells of $\mathrm{PBMC}$ and (B) spleen lymphocytes. ${ }^{* * *} \mathrm{P}<0.001$ vs. normal group; ${ }^{\# \# t} \mathrm{P}<0.001$ vs. model group. Mean \pm standard deviation from three independent experiments. PBMC, peripheral blood mononuclear cell; EAT, experimental autoimmune thyroiditis.

emodin lowered the EAT level partially by reducing the relative populations of $\mathrm{CD}^{+}{ }^{+} \mathrm{CD} 4^{+} \mathrm{IFN}-\gamma^{+}$and $\mathrm{CD} 3^{+} \mathrm{CD} 4^{+} \mathrm{IL}-4^{+} \mathrm{T}$ cells of PBMC and spleen lymphocytes.

Emodin down-regulated the relative populations of $\mathrm{CD}^{+} \mathrm{CD}^{+} \mathrm{IFN}-\gamma^{+}$and $\mathrm{CD} 3^{+} \mathrm{CD}^{+} \mathrm{IL}-4^{+} \mathrm{T}$ cells of PBMC and spleen lymphocytes in EAT NOD mice. In NaI-induced EAT NOD mice, the relative frequencies of $\mathrm{CD} 3^{+} \mathrm{CD} 8^{+} \mathrm{IFN}-\gamma^{+} \mathrm{T}$ and $\mathrm{CD} 3^{+} \mathrm{CD} 8{ }^{+} \mathrm{IL}-4^{+} \mathrm{T}$ cells of PBMC and spleen lymphocytes were found to be higher in the model and the emodin groups compared with the normal group (Fig. 6A and B). The number of $\mathrm{CD}^{+} \mathrm{CD} 8^{+} \mathrm{IFN}-\gamma^{+}$and $\mathrm{CD} 3^{+} \mathrm{CD} 8^{+} \mathrm{IL}-4^{+} \mathrm{T}$ cells of PBMC and spleen lymphocytes in the emodin group was lower compared with the model group, which indicated that emodin improved the EAT level partially by decreasing the relative populations of $\mathrm{CD}^{+} \mathrm{CD} 8^{+} \mathrm{IFN}-\gamma^{+}$and $\mathrm{CD}^{+}{ }^{+} \mathrm{CD}^{+}{ }^{+} \mathrm{IL}-4^{+} \mathrm{T}$ cells of PBMC and spleen lymphocytes (Fig. 6A and B). 
A
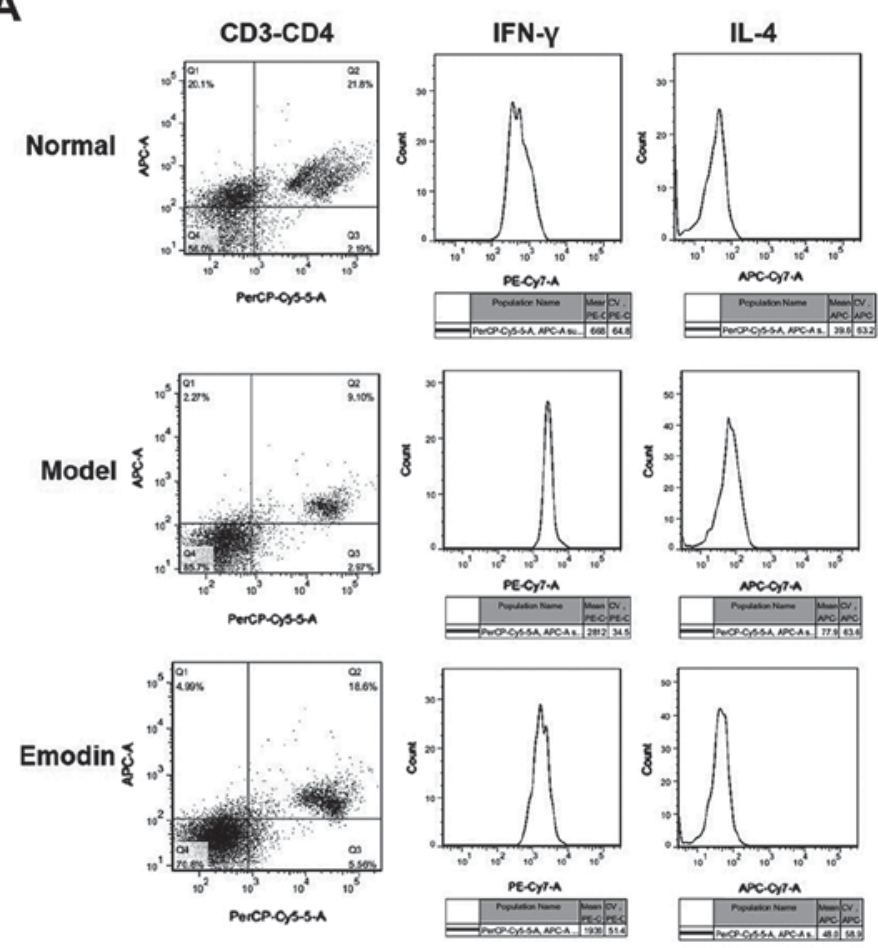

B
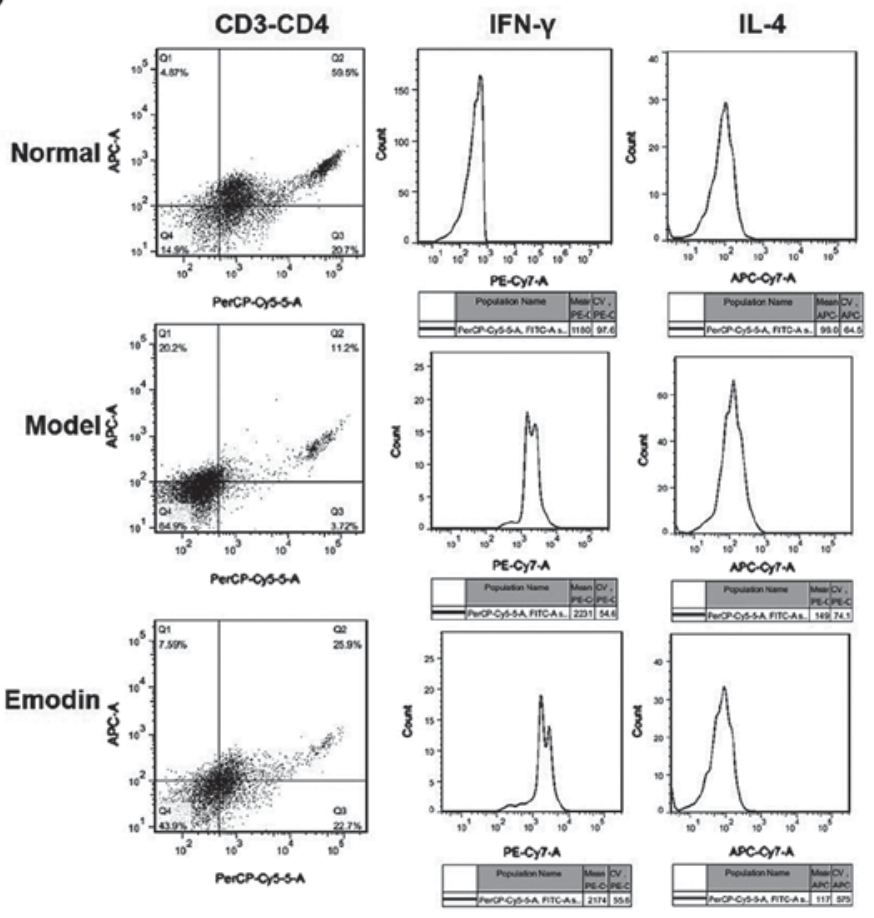
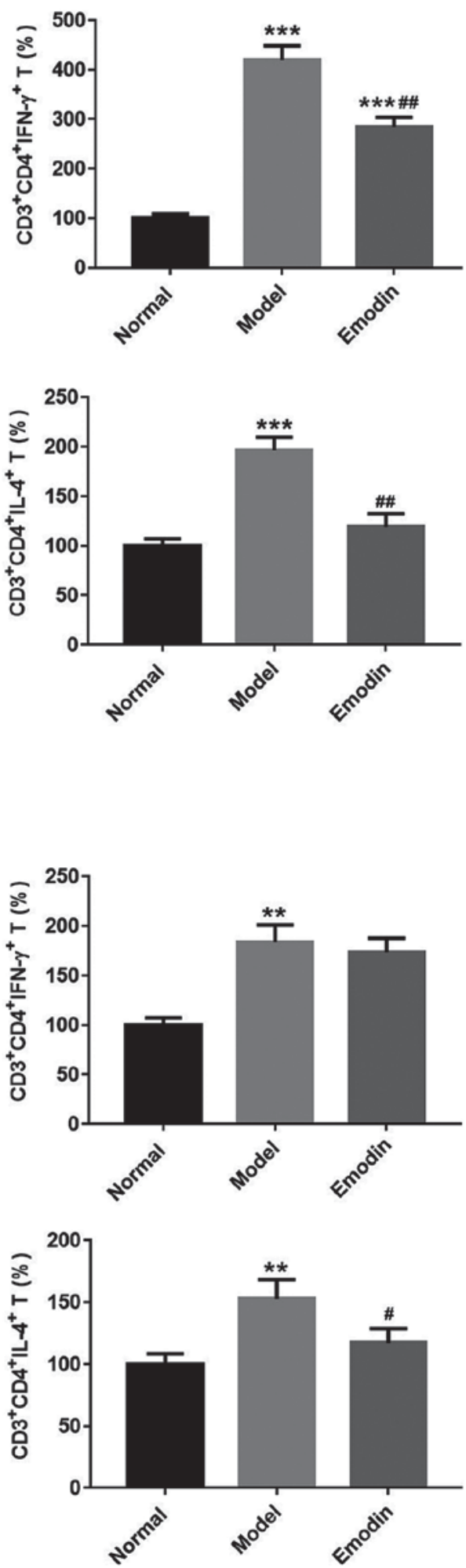

Figure 5. A total of $75 \mathrm{mg} / \mathrm{kg}$ emodin decreased the relative populations of $\mathrm{CD} 3^{+} \mathrm{CD} 4^{+} \mathrm{IFN}-\gamma^{+}$and $\mathrm{CD} 3^{+} \mathrm{CD} 4^{+} \mathrm{IL}-4^{+} \mathrm{T}$ cells of PBMC and spleen lymphocytes in EAT mice. PBMC and spleen lymphocyte were treated with $50 \mathrm{ng} / \mathrm{ml}$ phorbol ester and $1 \mu \mathrm{g} / \mathrm{ml}$ ionomycin for $6 \mathrm{~h}$. The relative populations of $\mathrm{CD} 3^{+} \mathrm{CD} 4{ }^{+} \mathrm{IFN}-\gamma^{+} \mathrm{T}$ cells and $\mathrm{CD} 3^{+} \mathrm{CD} 4^{+} \mathrm{IL}-4^{+} \mathrm{T}$ cells in PBMC and spleen lymphocytes were analyzed by flow cytometry. The relative populations of (A) $\mathrm{CD}^{+}{ }^{+} \mathrm{CD} 4{ }^{+} \mathrm{IFN}-\gamma^{+}$and $\mathrm{CD}^{+} \mathrm{CD} 4{ }^{+} \mathrm{IL}-4^{+} \mathrm{T}$ cells of PBMC and (B) spleen lymphocytes. ${ }^{* *} \mathrm{P}<0.01,{ }^{* * *} \mathrm{P}<0.001$ vs. normal group; ${ }^{*} \mathrm{P}<0.05$, ${ }^{, \#} \mathrm{P}<0.01$ vs. model group. Mean \pm standard deviation from three independent experiments. PBMC, peripheral blood mononuclear cell; EAT, experimental autoimmune thyroiditis.

\section{Discussion}

CLT and Graves' disease are the main two types of autoimmue thyroid disease. Previous studies in CLT demonstrated that this disease is related to the production of $\operatorname{Tg} \mathrm{Ab}$ and thyroid polyoxidase antibodies and the infiltration of monocytes in the thyroid tissues (19). CLT is influenced by a variety of factors including circumstance and heredity. The exact mechanism that underlies CLT is still unknown (19). In the present study, the effect of emodin on CLT was investigated by establishing 
A
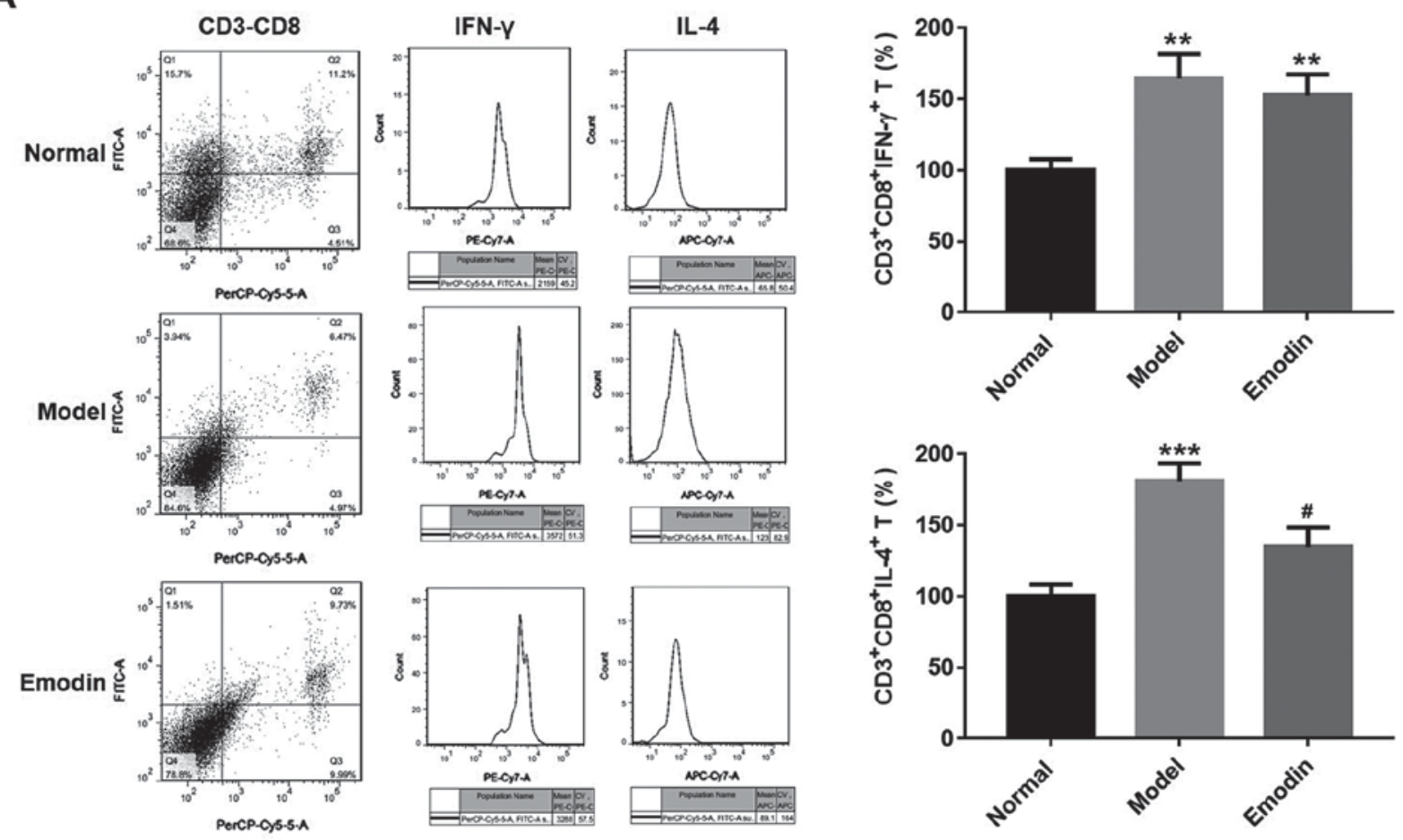

B
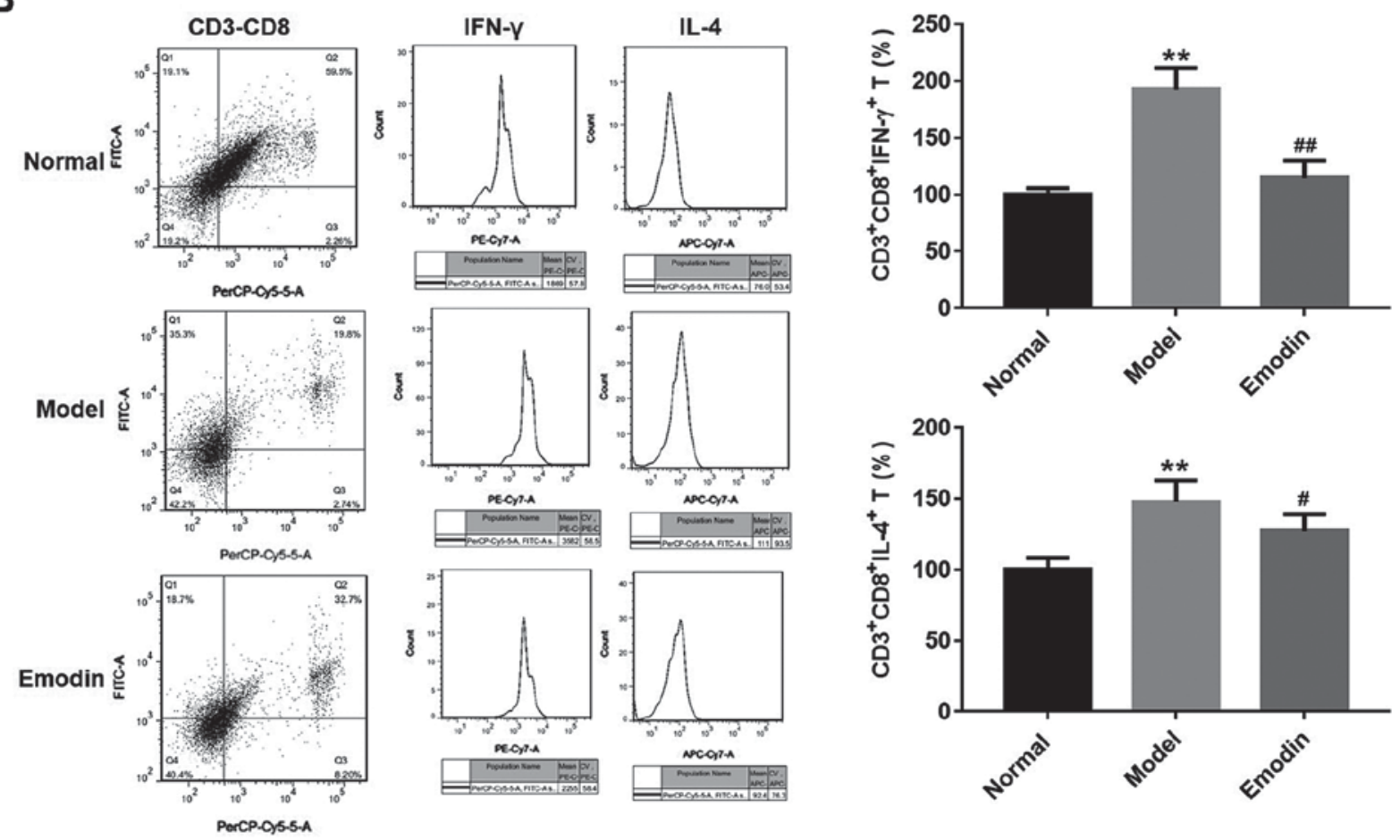

Figure 6. A total of $75 \mathrm{mg} / \mathrm{kg}$ emodin down-regulated the relative populations of $\mathrm{CD}^{+} \mathrm{CD} 8^{+} \mathrm{IFN}-\gamma^{+}$and $\mathrm{CD} 3^{+} \mathrm{CD} 8^{+} \mathrm{IL}-4^{+} \mathrm{T}$ cells of PBMC and spleen lymphocytes in EAT mice. The relative populations of $\mathrm{CD}^{+} \mathrm{CD} 8^{+} \mathrm{IFN}-\gamma^{+}$and $\mathrm{CD}^{+} \mathrm{CD} 8^{+} \mathrm{IL}-4^{+} \mathrm{T}$ cells in PBMC and spleen lymphocytes were analyzed by flow cytometry. The relative populations of (A) $\mathrm{CD}^{+}{ }^{+} \mathrm{CD} 8{ }^{+} \mathrm{IFN}-\gamma^{+}$and $\mathrm{CD} 3^{+} \mathrm{CD} 88^{+} \mathrm{IL}-4^{+} \mathrm{T}$ cells of PBMC and (B) spleen lymphocytes. ${ }^{* *} \mathrm{P}<0.01,{ }^{* * *} \mathrm{P}<0.001 \mathrm{vs}$. normal group; ${ }^{\#} \mathrm{P}<0.05,{ }^{\# \#} \mathrm{P}<0.01$ vs. model group. Mean \pm standard deviation from three independent experiments. PBMC, peripheral blood mononuclear cell; EAT, experimental autoimmune thyroiditis

an EAT animal model via administration of NaI in NOD mice. Based on the histopathological evaluation results and the levels of $\mathrm{TgAb}$, the animal model was successfully established. Emodin could effectively regulate $\mathrm{CD}^{+}{ }^{+} \mathrm{CD} 4^{+}$and $\mathrm{CD}^{+}{ }^{+} \mathrm{CD} 8^{+} \mathrm{T}$ cells in both PMBC and spleen lymphocytes.
Th1 and Th2 cytokines were balanced following treatment with emodin.

The dose of $75 \mathrm{mg} / \mathrm{kg} / \mathrm{d}$ was selected in the present study as the optimum dose. Emodin was reported to be effective in inhibiting the mutation of dendritic cells, reducing the action 
of lymphocytes and regulating the balance between Th1 and Th2 cytokines (10). Following treatment with emodin, the degree of severity of EAL in NOD mice was attenuated. The type of cytokines was important for the differentiation of the Th cells (17,20). Th1 cells are considered the differentiation cells derived from primary $\mathrm{CD}^{+} \mathrm{T}$ cells following induction by IFN- $\gamma$. In turn, IFN- $\gamma$ is secreted by Th1 cells $(17,20)$. The expression of HLA-II type antigen in thyroid epithelial cells could be enhanced by IFN- $\gamma$. The over-expression of the antigen triggers the production of autoimmunity. Subsequently, various monocytes and $\mathrm{T}$ lymphocytes are activated. Furthermore, the entrance of these activated cells in the thyroid causes an enhancement in cell toxicity and triggers antibody production $(17,20)$.

Previous studies could not reach a consensus with regard to the effect of cellular and humoral immunities in CLT. It has been suggested that the up-regulated levels of IFN- $\gamma$ could disrupt the balance between Th1 and Th2 cytokines and increase the levels of Th1. Cellular immunity was considered to be the main factor responsible for the development of CLT $(21,22)$. However, other studies have proposed that cellular immunity and humoral immunity are equally important in regulating CLT (23). Following treatment with NaI, the populations of $\mathrm{CD}^{+} \mathrm{CD} 4{ }^{+} \mathrm{IFN}-\gamma^{+}$and $\mathrm{CD} 3{ }^{+} \mathrm{CD} 8^{+} \mathrm{IFN}-\gamma^{+} \mathrm{T}$ cells in PBMC and spleen lymphocytes were significantly increased in NOD mice, which suggested that Th1 cells participated in the regulation of CLT. Furthermore, the populations of $\mathrm{CD}^{+} \mathrm{CD} 4^{+} \mathrm{IL}-4^{+}$and $\mathrm{CD} 3^{+} \mathrm{CD} 8^{+} \mathrm{IL}-4^{+} \mathrm{T}$ cells in $\mathrm{PBMC}$ and spleen lymphocytes were also increased to some extent in NOD mice, which suggested that Th2 cells were active in regulating CLT. It was reported by Yu that Th1 and Th2 play distinct roles during the stages of CLT (24). Th1 and Th2 cells are involved in the primary stage of inflammatory response and in the maintenance stage of CLT, whereas only Th2 cytokines may be involved in the maintenance stage of CLT. The data reported in the present study are consistent with previous investigations.

Following treatment with emodin, the populations of $\mathrm{CD}^{+}{ }^{+} \mathrm{CD} 4{ }^{+} \mathrm{IFN}-\gamma^{+}, \mathrm{CD}^{+}{ }^{+} \mathrm{CD} 8^{+} \mathrm{IFN}-\gamma^{+}, \mathrm{CD}^{+}{ }^{+} \mathrm{CD} 4^{+} \mathrm{IL}_{-} 4^{+}$and $\mathrm{CD}^{+}{ }^{+} \mathrm{CD} 8^{+} \mathrm{IL}-4^{+} \mathrm{T}$ cells in $\mathrm{PBMC}$ and spleen lymphocytes were markedly reduced in EAT NOD mice, which suggested that emodin was effective for the treatment of CLT. Based on this evidence, emodin was suggested as an effective protein involved in cellular and humoral immunities. In the present study, the effect of emodin on the regulation of CLT was demonstrated using an EAT NOD mice model. The possible mechanism of this action was further studied. This is the first study to report the effects of emodin on CLT and the data provide evidence to support the further clinical use of emodin. In conclusion, emodin shows promise for the treatment of CLT and can be investigated further in future studies.

\section{Acknowledgements}

Not applicable.

\section{Funding}

No funding was received.

\section{Availability of data and materials}

The datasets used and/or analyzed during the current study are available from the corresponding author on reasonable request.

\section{Authors' contributions}

ZY, HS, NL, FJ and KW collaborated in the experimental design, tissue collection and experiment execution. ZY, JY and HS analyzed and interpreted the data and were the major contributors in developing the first draft of this manuscript. FJ reviewed and edited this manuscript. JY and KW reviewed and approved the final draft of this manuscript before submission.

\section{Ethics approval and consent to participate}

Ethics approval for the study was given by the First Affiliated Hospital of Zhejiang Chinese Medical animal experimental ethics committee.

\section{Patient consent for publication}

Not applicable.

\section{Competing interests}

The authors declare that they have no competing interests.

\section{References}

1. Zhang Y, Ma XP, Deng FS, Liu ZR, Wei HQ, Wang XH and Chen $\mathrm{H}$ : The effect of chronic lymphocytic thyroiditis on patients with thyroid cancer. World J Surg Oncol 12: 277, 2014.

2. Antonaci A, Consorti F, Mardente S and Giovannone G: Clinical and biological relationship between chronic lymphocytic thyroiditis and papillary thyroid carcinoma. Oncol Res 17: 495-503, 2009.

3. Iliadou PK, Effraimidis G, Konstantinos M, Grigorios P, Mitsakis P, Patakiouta F and Pazaitou-Panayiotou K: Chronic lymphocytic thyroiditis is associated with invasive characteristics of differentiated thyroid carcinoma in children and adolescents. Eur J Endocrinol 174: X1, 2016.

4. Yu L, Zhou L, Xu E, Bi Y, Hu X, Pei X and Jin G: Levothyroxine monotherapy versus levothyroxine and selenium combination therapy in chronic lymphocytic thyroiditis. J Endocrinol Invest 40: 1243-1250, 2017.

5. Guimaraes VC, Quintans J, Fisfalen ME, Straus FH, Wilhelm K, Medeiros-Neto A and Degroot LJ: Suppression of development of experimental autoimmune thyroiditis by oral administration of thyroglobulin. Endocrinology 136: 3353-3359, 1995.

6. Hoshikawa S, Nakagawa Y, Ozaki H, Takahashi Y, Ito S, Yoshida K and Mori K: Effects of green tea polyphenols on iodide-induced autoimmune thyroiditis in nonobese diabetic mice. Immunol Invest 42: 235-246, 2013.

7. Morris GP, Brown NK and Kong YC: Naturally-existing CD4(+)CD25(+)Foxp3(+) regulatory $\mathrm{T}$ cells are required for tolerance to experimental autoimmune thyroiditis induced by either exogenous or endogenous autoantigen. J Autoimmun 33: 68-76, 2009.

8. Song XH, Zan RZ, Yu CH and Wang F: Effects of modified Haizao Yuhu Decoction in experimental autoimmune thyroiditis rats. J Ethnopharmacol 135: 321-324, 2011.

9. Yu X, Li L, Li Q, Zang X and Liu Z: TRAIL and DR5 promote thyroid follicular cell apoptosis in iodine excess-induced experimental autoimmune thyroiditis in NOD mice. Biol Trace Elem Res 143: 1064-1076, 2011.

10. Dong X, Fu J, Yin X, Cao S, Li X, Lin L, Huyiligeqi and Ni J: Emodin: A review of its pharmacology, toxicity and pharmacokinetics. Phytother Res 30: 1207-1218, 2016. 
11. Trybus W, Król T, Trybus E, Kopacz-Bednarska A, Król G and Karpowicz E: Changes in the lysosomal system of cervical cancer cells induced by emodin action. Anticancer Res 37: 6087-6096, 2017.

12. Dai JP, Wang QW, Su Y, Gu LM, Zhao Y, Chen XX, Chen C, Li WZ, Wang GF and Li KS: Emodin inhibition of influenza A virus replication and influenza viral pneumonia via the Nrf2, TLR4, p38/JNK and NF-kappaB pathways. Molecules 22: pii: E1754, 2017.

13. Yan L, Hu R, Tu S, Cheng WJ, Zheng Q, Wang JW, Kan WS and Ren YJ: Emodin mitigates the oxidative stress induced by cisplatin in osteosarcoma MG63 cells. Oncol Lett 12: 1981-1985, 2016.

14. Zu C, Zhang M, Xue H, Cai X, Zhao L, He A, Qin G, Yang C and Zheng X: Emodin induces apoptosis of human breast cancer cells by modulating the expression of apoptosis-related genes. Oncol Lett 10: 2919-2924, 2015.

15. Qiu F, Liu H, Liang CL, Nie GD and Dai Z: A new immunosuppressive molecule emodin induces both $\mathrm{CD} 4+\mathrm{FoxP} 3+$ and $\mathrm{CD} 8+\mathrm{CD} 122+$ regulatory $\mathrm{T}$ cells and suppresses murine allograft rejection. Front Immunol 8: 1519, 2017.

16. Guzman RE and Radi ZA: Chronic lymphocytic thyroiditis in a cynomolgus macaque (Macaca fascicularis). Toxicol Pathol 35: 296-299, 2007.

17. Tang H, Mignon-Godefroy K, Meroni PL, Garotta G, Charreire J and Nicoletti F: The effects of a monoclonal antibody to interferon-gamma on experimental autoimmune thyroiditis (EAT) Prevention of disease and decrease of EAT-specific T cells. Eur J immunol 23: 275-278, 1993.

18. Wang X, Liu H, Zhang Y, Li J, Teng X, Liu A, Yu X, Shan Z and Teng W: Effects of isolated positive maternal thyroglobulin antibodies on brain development of offspring in an experimental autoimmune thyroiditis model. Thyroid 25 : $551-558,2015$.
19. Shoenfeld Y, Zandman-Goddard G, Stojanovich L, Cutolo M, Amital H, Levy Y, Abu-Shakra M, Barzilai O, Berkun Y, Blank M, et al: The mosaic of autoimmunity: hormonal and environmental factors involved in autoimmune diseases-2008. Isr Med Assoc J 10: 8-12, 2008.

20. Jacobson EM, Huber A and Tomer Y: The HLA gene complex in thyroid autoimmunity: from epidemiology to etiology. J Autoimmun 30: 58-62, 2008.

21. Watanabe M, Yamamoto N, Maruoka H, Tamai H, Matsuzuka F, Miyauchi A and Lwatani Y: Independent involvement of CD8+ CD25+ cells and thyroid autoantibodies in disease severity of Hashimoto's disease. Thyroid 12: 801-808, 2002.

22. Vasu C, Dogan RN, Holterman MJ and Prabhakar BS: Selective induction of dendritic cells using granulocyte macrophage-colony stimulating factor, but not fms-like tyrosine kinase receptor 3-ligand, activates thyroglobulin-specific CD4+/CD25+ $\mathrm{T}$ cells and suppresses experimental autoimmune thyroiditis. J immunol 170: 5511-5522, 2003

23. Liu T, Yu ZQ, Zou HJ, Liu SS, Fan CL, Teng WP, Shan ZY and Li YS: Study of microRNA-155 changes in iodine-induced autoimmune thyroiditis model of NOD. H-2 h4 mice. Chin J Immunol 31: 936-941, 2015 (In Chinese).

24. Yu S, Sharp GC and Braley-Mullen H: Dual roles for IFN-gamma, but not for IL-4, in spontaneous autoimmune thyroiditis in NOD.H-2h4 mice. J immunol 169: 3999-4007, 2002.

(i) $\ominus$ This work is licensed under a Creative Commons Attribution-NonCommercial-NoDerivatives 4.0 International (CC BY-NC-ND 4.0) License. 